\title{
Autochthonous case of dengue in France, October 2013
}

\author{
E Marchand (ars-paca-cire@ars.sante.fr) ${ }^{1}$, C Prat ${ }^{2}$, C Jeannin ${ }^{3}$, E Lafont ${ }^{4}$, T Bergmann $^{1}$, 0 Flusin ${ }^{2}$, J Rizzi ${ }^{4}$, N Roux $^{4}$, V Busso $^{5}$, J \\ Deniau $^{6}$, H Noel $^{7}$, V Vaillant 7 , I Leparc-Goffart ${ }^{2}$, C Six ${ }^{1}$, M C Paty $^{7}$ \\ 1. Regional office of the French Institute for Public Health Surveillance (Cire Sud), Marseille, France \\ 2. Institut de Recherche Biomédicale des Armées, National Reference Laboratory for arboviruses, Marseille, France \\ 3. Entente Interdépartementale pour la Démoustification du littoral Méditerranéen (EID méditerranée), Public mosquito control \\ agency, Montpellier, France \\ 4. Regional Health Agency of Provence-Alpes-Côte d’Azur, Marseille, France \\ 5. Laboratory Network Bioactif, Bouches-du-Rhône, France \\ 6. Emergency services regional observatory of Provence-Alpes-Côte d'Azur, Hyères, France \\ 7. French Institute for Public Health Surveillance (Institut de Veille Sanitaire, InVS), Saint-Maurice, France
}

Citation style for this article:

Marchand E, Prat C, Jeannin C, Lafont E, Bergmann T, Flusin O, Rizzi J, Roux N, Busso V, Deniau J, Noel H, Vaillant V, Leparc-Goffart I, Six C, Paty MC.

Autochthonous case of dengue in France, October 2013. Euro Surveill. 2013;18(50):pii=20661. Available online: http://www.eurosurveillance.org/ViewArticle. Autochthonous case of
aspx?Articleld $=20661$

In October 2013, autochthonous dengue fever was diagnosed in a laboratory technician in Bouches-duRhône, southern France, a department colonised by Aedes albopictus since 2010. After ruling out occupational contamination, we identified the likely chain of local vector-borne transmission from which the autochthonous case arose. Though limited, this second occurrence of autochthonous dengue transmission in France highlights that efforts should be continued to rapidly detect dengue virus introduction and prevent its further dissemination in France.

In October 2013, the French National Reference Laboratory for arboviruses (NRL) - hosted at the Institut de Recherche Biomedicale des Armées, Marseille reported an autochthonous case of dengue fever to the Regional Health Authority of Provence-Alpes-Côte d'Azur. The case lived in the department of Bouchesdu-Rhône, France. The national and regional health authorities initiated a multidisciplinary investigation to determine the source of infection of the case and the extent of possible dissemination of dengue virus (DENV).

\section{Case report}

On 11 October 2013, a female laboratory technician in her early fifties, residing and working in the area of Aix-en-Provence, Bouches-du-Rhône department, developed sudden fever with incapacitating myalgia, predominantly in her legs. She had not left the department in the 15 days before onset of symptoms. Four days later, she developed a rash on her legs and consulted her general practitioner, who prescribed symptomatic treatment of fever and aches. As the symptoms persisted, she was taken to a hospital's emergency department on two days later. On admission to hospital, she was normotensive, with a body temperature of $38.4{ }^{\circ} \mathrm{C}$. Laboratory analyses showed a normal white blood cell (7,200/mL; norm: 4,000-10,000 /mL) and platelet count (197,000/mL; norm: 150,000-450,000/
$\mathrm{mL}$ ) and an elevated C-reactive protein level (145 mg/L; norm: $17.5 \mathrm{mg} / \mathrm{L})$. As her condition had improved, despite the rash having expanded to her arms and back, she was discharged after 24 hours, with a diagnosis of 'probable viral infection'. She consulted a dermatologist three days later, who suspected an arboviral infection and sent blood samples to the NRL.

A panel of sera obtained during the acute and convalescent phases (days 6,10, 14 and 35 after symptom onset) was investigated using in-house real-time reverse transcription polymerase chain reaction (RT-PCR) and serological assays (in-house IgM antibody capture (MAC)-enyzme-linked immunosorbent assay (ELISA) and indirect IgG ELISA) for DENV and West Nile, chikungunya and Toscana viruses (Table). For the first serum sampled on day 6, the real-time RT-PCR for DENV was positive, with a high cycle threshold $(\mathrm{Ct})$ value (indicating a very low viral load), serotyping by real-time RT-PCR was negative, DENV non-structural protein 1 (NS1) detection by rapid diagnostic test (SD Bioline) was negative, but IgM and IgG antibodies against DENV antigens were detected). IgM and IgG antibodies against DENV were also detected in the next two serum samples (on days 10 and 14). For the last serum specimen, sampled on day 35 , only DENV-specific IgG antibodies were detected: the specificity of these antibodies was determined by seroneutralisation against DENV serotypes 1 to 4 (DEN1-4) and West Nile virus [1]. For West Nile virus, DEN1, DEN 3 and DEN4, the $90 \%$ neutralisation titre was $<1 / 20$. A $90 \%$ neutralisation titre of $1 / 160$ against DEN-2 was highly suggestive of an infection of this patient by DEN-2.

\section{Background}

Infection with DENV - a member of the family Flaviviridae, genus Flavivirus - leading to dengue haemorrhagic fever and shock syndrome, is responsible for substantial morbidity and mortality in populations living in the tropics and among travellers to these 


\section{FIGURE 1}

Timeline of epidemiological features and laboratory results of sera from autochthonous and imported case of dengue, Bouches-du-Rhône, France, September-November 2013

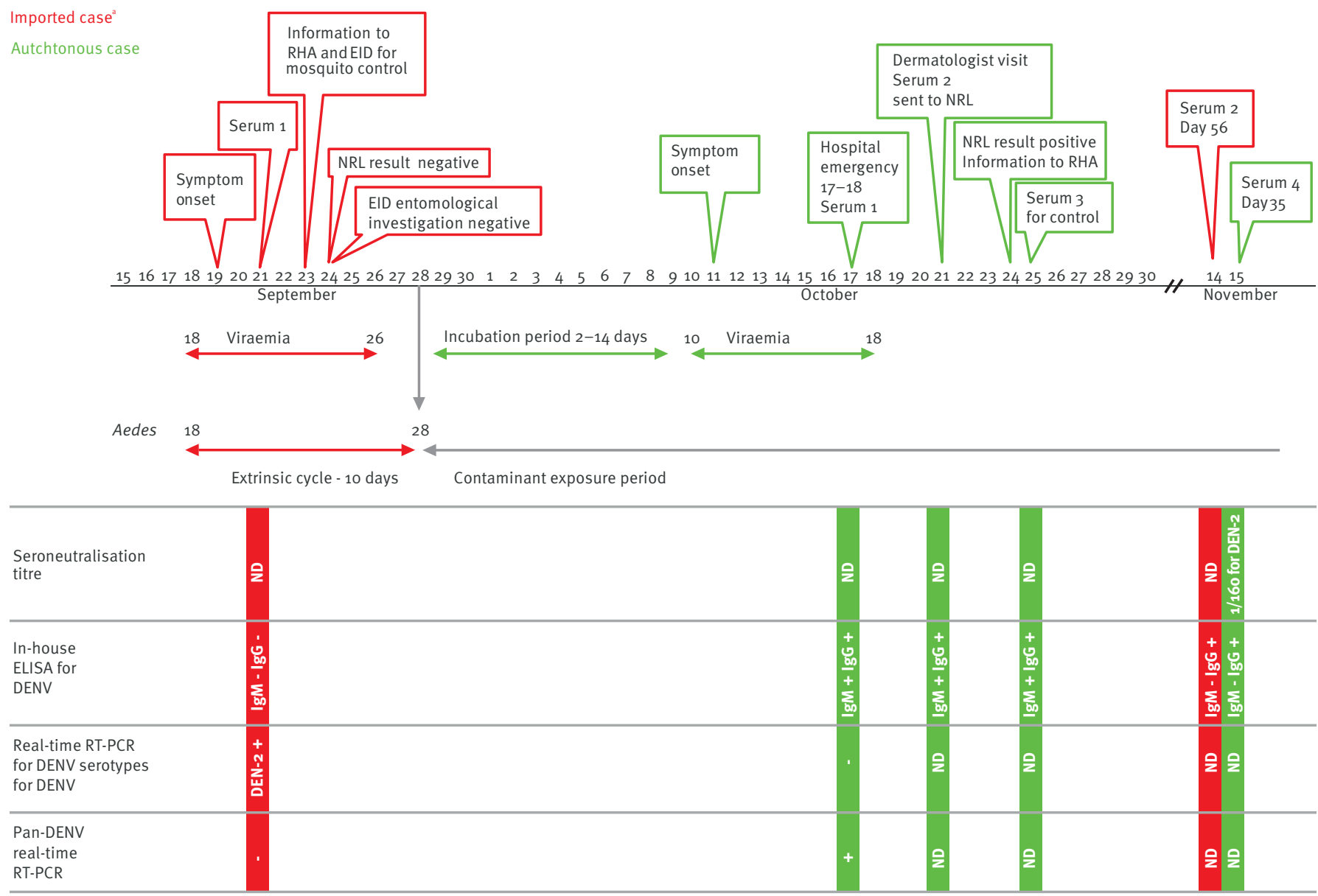

DENV: dengue virus; EID: Entente Interdépartementale pour la Démoustification du littoral Méditerranéen; ELISA: enzyme-linked immunosorbent assay; ND: not done; NLR: National Reference Laboratory for arboviruses; RHA: regional health agency ; RT-PCR: reverse transcription polymerase chain reaction.

a Initially reported as a suspected case.

regions [2,3]. The global burden of dengue ranges from an estimated 50-100 million DENV infections worldwide every year according to the World Health Organization [3] to a recent estimate of 390 million DENV infections per year [4]. The virus is considered an emerging threat to Europe because of its recent detection in southern Europe due to the continuous spread of Aedes (Stegomyia) albopictus (Skuse), an invasive mosquito species and well-known vector of chikungunya virus and DENV $[5,6]$. Public health concern has been heightened since limited foci of local transmission of DENV were reported in September 2010 in Nice, southern France, and Croatia and more recently in 2012 in Madeira, Portugal (where the vector was Ae. aegypti) [7-9].

Ae. albopictus was introduced in southern France in 2004, near the Italian border [10]. Since then, it has continuously spread eastwards and northwards and has to date colonised 17 departments (administrative districts) including Bouches-du-Rhône since 2009 (Figure 2) $[10,11]$. Prevention of the introduction of DENV and chikungunya virus in the departments where Ae. albopictus is established falls under a national preparedness and response plan created in 2006 [12]. Implemented each year during the vector activity period, from 1 May to 30 November, the plan is based on enhanced surveillance aiming at the early detection of imported dengue and chikungunya cases.

In mainland France, dengue has been a mandatorily notifiable disease since April 2006 [13]: a case should be reported immediately after laboratory confirmation [12]. In addition, in the areas and period of vector activity, physicians and laboratories are asked to immediately notify suspected imported cases to the local health authorities and to send blood samples directly to the NRL for laboratory confirmation. These actions 


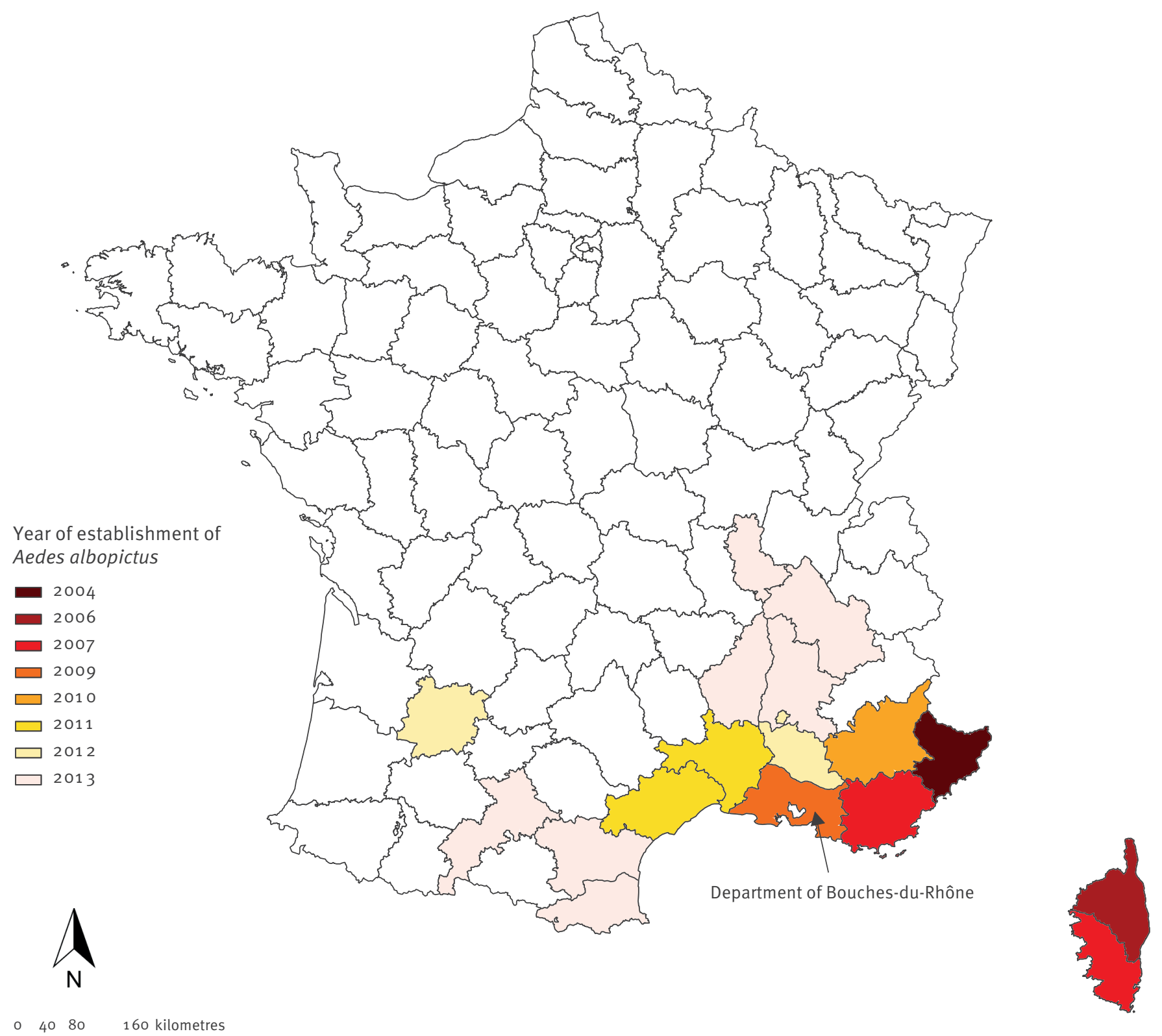

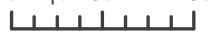

Source: IGN-GéoFLA, 1999; French Institute for Public Health Surveillance (Institut de Veille Sanitaire, InVS), 2013.

guide entomological investigations followed by vector control measures when appropriate.

\section{The investigation}

As the case could have been exposed to blood during her laboratory work, two hypotheses on the source of infection and mode of DENV transmission were explored: occupational transmission through accidental exposure to blood from a viraemic patient or local vector-borne transmission.

\section{Occupational transmission}

Considering an incubation period of 2 to 14 days, in agreement with earlier reports of occupational DENV infection [14-16], we defined the period of likely exposure as 27 September to 8 October. The autochthonous case carried out on average 60 venous punctures a day from patients. She had no recollection of any direct blood exposure during this period. However, she reported not wearing gloves while collecting blood and presented skin excoriations on her fingers. Among patients sampled in her workplace, none had blood taken for dengue fever suspected by a physician. Nevertheless, we screened for DENV all patients sampled in the laboratory during the case's likely period of infection who presented with symptoms of or a history compatible with dengue. The criteria for screening were fever without diagnosis, reported travel in an 
area where dengue was reported, leucopenia, thrombocytopenia, hepatic cytolysis, negative viral serology and negative rapid or blood smear tests for malaria. The NRL conducted DENV real-time RT-PCR and serology on the 15 blood samples still available from the 18 patients who met the selection criteria. All tested negative.

\section{Vector-borne transmission}

The patient reported no mosquito bites but remembered a sudden pricking sensation compatible with a mosquito bite on the evening of 3 October (eight days before symptom onset), when she was near her workplace in Bouches-du-Rhône. She reported no recent contact with travellers returning from an area with current epidemics or endemic for dengue.

A review of the surveillance database did not identify any case of imported dengue confirmed by the NRL in Bouches-du-Rhône since 1 August 2013. However, one suspected case had been notified in a neighbouring department in a woman who developed fever and a rash on 19 September, five days after returning from the Caribbean island of Guadeloupe, where a dengue outbreak was ongoing [17]. Sera collected on day 2 of her illness tested negative for DENV, West Nile, chikungunya and Saint Louis encephalitis viruses by our in-house real-time RT-PCR and serological assays. An entomological investigation of her residential area and places visited had been carried out on 24 September, before the negative test results were available. Among the places visited, the woman mentioned a short visit, the day before symptom onset, close to (less than 200 metres from) the workplace of the autochthonous case. Although an ovitrap placed nearby this workplace had been found colonised with 43 eggs of Ae. albopictus in late September 2013, no evidence of mosquito activity was found during an investigation on 23 September, hence no vector control measures were implemented at that time.

After the detection of the autochthonous case, we retested the serum sample of the suspected imported case by sero-specific real-time RT-PCR for DENV and by rapid diagnostic test for NS1 detection. An additional serum sample was collected on day 56 for serology testing. The NS1 test and the pan-DENV real-time RT-PCR were negative, the real-time RT-PCR for DEN-2 was positive with a high $\mathrm{Ct}$ value. In the later serum sample (day 56), only IgG antibodies against DENV were detected. These laboratory findings confirmed an infection with DEN-2 for this patient returning from Guadeloupe (considered the index case).

\section{Control measures}

Under the hypothesis of local vector-borne transmission, two places were chosen for identifying primary or secondary cases of DENV infection and for conducting immediate control measures: the autochthonous case's home, where she stayed while viraemic, and her place of work close to which eggs of Ae. albopictus had been detected in September.

The local health authorities and vector control operators jointly carried out the following activities in an area of 200 metres around the autochthonous case's home and workplace: door-to-door case finding; any mosquito breeding sites treated by mechanical destruction or larvicide treatment sites; and adulticide sprayings. Physicians and laboratories in the area were asked to report any patients with symptoms compatible with DENV infection since 1 August, including sudden onset of fever $\left(38.5^{\circ} \mathrm{C}\right)$ and at least one pain symptom, including headache, arthralgia, myalgia, lower back pain or retro-orbital pain. Two suspected cases were identified. Neither tested positive for DENV by real-time RT-PCR or serology.

\section{Discussion}

This second report of autochthonous dengue in mainland France follows a cluster of two locally acquired cases in Alpes-Maritimes in 2010 [7]. Because our patient was a laboratory technician who daily collected blood specimens, we not only explored vector-borne local transmission of DENV but also thoroughly investigated potential occupational transmission. The latter hypothesis appears unlikely since, unlike the situation for other occupational dengue cases [14-16], our investigation pinpointed neither a viraemic or infected patient sampled nor any accidental exposure to blood at the laboratory during the likely exposure period of the case.

Several findings are in favour of vector-borne transmission in the Bouches-du-Rhône department. Firstly, our retrospective laboratory confirmation of an imported case of dengue, who had visited the immediate vicinity of the autochthonous case's workplace, while potentially viraemic (one day before symptom onset). Secondly, the 22-day delay between symptom onset of the imported and autochthonous case, which is compatible with the intrinsic (1-14 days) and extrinsic (10 days) incubation period for DENV [18]. Thirdly, the presence of Ae. albopictus eggs in the ovitraps in September, indicating the presence of the potential vector. Finally, laboratory confirmation of DENV infection of the same serotype, DEN-2, in both the autochthonous case and the case imported from Guadeloupe. In August to October 2013, DEN-2 was not the prevailing circulating serotype in Guadeloupe, but remained frequent [17].

The virological data presented in this paper on the two human cases of DENV infection do not follow the classical and average kinetics of viraemia and antibody response. The individual host response is known to be variable regarding the viral load in blood, the duration of viraemia and the duration of IgM detection and is also dependent on the DENV responsible for the infection $[19,20]$. Unfortunately, although viral RNA was detected in the acute phase sample of the autochthonous case, 
we were unable to serotype and sequence the amplified product due to a very low viral load. Further comparison of the virus isolates by sequencing is therefore impossible. Two blind passages on Vero and $\mathrm{C} 6 / 36$ cell lines will be carried out to try to isolate the virus from the acute phase sera. NS1 was not detected for these two cases. However, the detection of NS1 is generally less sensitive than viral genome detection by real-time RT-PCR $[20,21]$.

This local transmission of dengue highlights once again that mainland France is subject to overspill of dengue outbreaks, particularly from the French Antilles in the Caribbean. The implemented investigations and control measures were derived from a national plan against dengue and chikungunya that provides a framework for rapid review and exchange of information between epidemiological, entomological, laboratory and medical experts and decision-makers.

The autochthonous case was diagnosed only after a third and specialised medical consultation. We need therefore to further raise the awareness of physicians and laboratories regarding diagnosis of dengue in international travellers and the possibility of autochthonous transmission in areas where Ae. albopictus is established. Similarly, we should not discontinue our efforts to inform travellers to areas affected by dengue about individual protection against mosquito bites and early symptoms of dengue.

No further case could be related to this local transmission cycle of dengue in Bouches-du-Rhône. Although precautionary mosquito control was applied, this could very well have been a self-limiting viral dissemination since it occurred shortly before the end of the vector activity period in late November.

\section{Conclusion}

Although limited, this autochthonous transmission of DENV in southern France is a clear reminder that local transmission can be triggered in Europe by the introduction of the virus in areas colonised by Ae. albopictus, as it occurred already in 2010 in Nice. The French preparedness and response plan, in operation since 2006, proved pivotal to detect and control this threat.

Reducing the risk of local DENV dissemination to zero appears an elusive goal in the context of the continuous spread of Ae albopictus. Coordinated enhanced surveillance and response are therefore the backbone of the prevention of the occurrence of autochthonous cases and the containment of possible outbreaks. Such a plan requires, however, multidisciplinary expertise and resources and should be adapted wisely and regularly to ensure its sustainability and efficiency. In addition, innovative vector control methods and further elucidation of the dynamics of DENV transmission in non-endemic areas are needed to keep Europe safe from dengue.
Acknowledgements

The biomedical laboratories involved in the enhanced surveillance: Cerba (Saint-Ouen l'Aumone), Biomnis (Lyon) and La Timone (Marseille), part of the national laboratory surveillance system, and the private laboratories in southern France; vector control professionals at EID Méditerranée; Dr Didier Fontenille, Yvon Perrin entomological expert at IRD (French Institute for Research and Development), Montpellier, France; Dr Catherine Guichard, Directorate General for Health, Ministry of Health, Paris, France; Dr Henriette De Valk and Lisa King for reviewing our manuscript, InVS, France. The patients and their relatives, colleagues and neighbours approached for this investigation.

\section{Conflict of interest}

None declared.

Authors' contributions

All authors contributed to the writing of this manuscript and approved the final version. Elodie Marchand, Caroline Six, Harold Noel, Veronique Vaillant, Marie-Claire Paty drafted the manuscript and contributed to the epidemiological investigation. Caroline Six, Harold Noel designed the protocol for the rapid survey. Thibaut Bergmann, Nicolas Roux, Jeanne Rizzi contributed to the epidemiological investigation. Elisabeth Lafont and Valerie Busso conducted interviews and took part in the clinical management of the patients. Joël Deniau contributed to the epidemiological investigation and managed the national database for enhanced surveillance of dengue and chikungunya. Caroline Six coordinated the investigation at the regional level. Christine Prat, Olivier Flusin, Isabelle Leparc-Goffart were central in the laboratory investigation. Marie-Claire Paty coordinated the investigation at the national level.

\section{References}

1. World Health Organization (WHO). Guidelines for plaque reduction neutralization testing of human antibodies to dengue viruses. Geneva: WHO; 2007. WHO/IVB/07.07. Available from: http://whqlibdoc.who.int/hq/2007/who_ivb_07.07_eng.pdf

2. Gautret P, Cramer JP, Field V, Caumes E, Jensenius M, Gkrania-Klotsas E, et al. Infectious diseases among travellers and migrants in Europe, EuroTravNet 2010. Euro Surveill. 2012;17(26):pii=20205. Available from: http://www. eurosurveillance.org/ViewArticle.aspx?Articleld=20205

3. World Health Organization (WHO). Dengue: guidelines for diagnosis, treatment, prevention and control. Geneva: WHO; 2009. WHO/HTM/NTD/DEN/2009.1. Available from: http:// whqlibdoc.who.int/publications/2009/9789241547871_eng.pdf

4. Bhatt S, Gething PW, Brady OJ, Messina JP, Farlow AW, Moyes $\mathrm{CL}$, et al. The global distribution and burden of dengue. Nature. 2013;496(7446):504-7.

http://dx.doi.org/10.1038/nature12060 PMid:23563266 PMCid:PMC3651993

5. Schaffner F, Medlock JM, Van Bortel W. Public health significance of invasive mosquitoes in Europe. Clin Microbiol Infect. 2013;19(8):685-92.

http://dx.doi.org/10.1111/1469-0691.12189 PMid:23574618

6. Paupy C, Delatte H, Bagny L, Corbel V, Fontenille D. Aedes albopictus, an arbovirus vector: from the darkness to the light. Microbes Infect. 2009:11(14-15):1177-85. http://dx.doi.org/10.1016/j.micinf.2009.05.005 PMid:19450706

7. La Ruche G, Souarès Y, Armengaud A, Peloux-Petiot F, Delaunay $P$, Desprès $P$, et al. First two autochthonous dengue virus infections in metropolitan France, September 2010. Euro Surveill. 2010;15(39):pii=19676. Available from: http://www. eurosurveillance.org/ViewArticle.aspx?Articleld=19676 PMid:20929659

8. Schmidt-Chanasit J, Haditsch M, Schöneberg I, Günther S, Stark K, Frank C. Dengue virus infection in a traveller returning from Croatia to Germany. Euro Surveill. 2010;15(40):pii=19677. 
Available from: http://www.eurosurveillance.org/ViewArticle. aspx?Articleld $=19677$

PMid:20946759

9. Alves MJ, Fernandes PL, Amaro F, Osório H, Luz T, Parreira

$P$, et al. Clinical presentation and laboratory findings for the first autochthonous cases of dengue fever in Madeira island, Portugal, October 2012. Euro surveill. 2013;18(6): pii=20398. Available from: http://www.eurosurveillance.org/ViewArticle. aspx?Articleld $=20398$

PMid:23410256

10. Delaunay P, Mathieu B, Marty P, Fauran P, Schaffner F. [Chronology of the development of Aedes albopictus in the Alpes-Maritimes Department of France, from 2002 to 2005]. Med Trop (Mars). 2007;67(3):310-1. French.

11. Delaunay P, Jeannin C, Schaffner F, Marty P. [News on the presence of the tiger mosquito Aedes albopictus in metropolitan France]. Arch Pediatr. 2009;16 Suppl 2:S66-S71. French.

http://dx.doi.org/10.1016/S0929-693X(09)75304-7

12. Instruction $N^{\circ}$ DGS/RI1/2013/182 du 30 avril 2013 mettant à jour le guide relatif aux modalités de mise en oeuvre du plan anti-dissémination du chikungunya et de la dengue en métropole. [Order updating the French preparedness and response plan against expansion of chikungunya and dengue fever in mainland France]. Paris: Ministry of health; 2013. French. Available from: http://circulaires.legifrance.gouv.fr/ pdf/2013/05/cir_37044.pdf

13. Décret $n^{\circ} 2006-433$ du 24 April 2006 complétant la liste des maladies faisant l'objet d'une transmission obligatoire de données individuelles à l'autorité sanitaire. [Decree updating the list of statutory notified diseases with transmission of individual data to the health authority]. Paris: République française; 2006. Available from: http://www.legifrance.gouv. $\mathrm{fr} /$ affichTexte.do?cidTexte=JORFTEXTooooo0455594

14. Clark BM, Molton JS, Habib T, Williams DT, Weston EL, Smith DW. Dengue virus infection in Australia following occupational exposure: a reflection of increasing numbers of imported cases. J Clin Virol. 2012;54(4):376-7. http://dx.doi.org/10.1016/j.jcv.2012.04.012 PMid:22621878

15. Nemes Z, Kiss G, Madarassi EP, Peterfi Z, Ferenczi E, Bakonyi $\mathrm{T}$, et al. Nosocomial transmission of dengue. Emerg Infect Dis. 2004;10(10):1880-1.

http://dx.doi.org/10.3201/eid1010.040464

PMid:15515246 PMCid:PMC3323269

16. Wagner D, de With K, Huzly D, Hufert F, Weidmann M,

Breisinger S, et al. Nosocomial acquisition of dengue. Emerg Infect Dis. 2004;10(10):1872-3.

http://dx.doi.org/10.3201/eid1010.031037

PMid:15504282 PMCid:PMC3323263

17. Situation épidémiologique de la dengue en Guadeloupe. Point au 27 novembre 2013. [Epidemiological situation of dengue fever in Guadeloupe. November 27th, 2013]. Fort-de-France, Martinique, Saint-Maurice: Institut de Veille Sanitaire; 2013 French. Available from: http://www.invs.sante.fr/fr/content/ download/80339/292895/version/35/file/pe_dengue_ guadeloupe_271113.pdf

18. Chan M, Johansson MA. The incubation periods of Dengue viruses. PLoS One. 2012;7(11):e50972.

http://dx.doi.org/10.1371/journal.pone.0050972 PMid:23226436 PMCid:PMC3511440

19. Tang Y, Kou Z, Zhang F, Yao X, Liu S, Ma J, et al. Both viremia and cytokine levels associate with the lack of severe disease in secondary dengue 1 Infection among adult Chinese patients. PLoS One. 5(12):e15631.

http://dx.doi.org/10.1371/journal.pone.0015631

PMid:21206915 PMCid:PMC3012067

20. Duyen HT, Ngoc TV, Ha do T, Hang VT, Kieu NT, Young PR, et al. Kinetics of plasma viremia and soluble nonstructural protein 1 concentrations in dengue: differential effects according to serotype and immune status. J Infect Dis. 2011;203(9):1292300.

http://dx.doi.org/10.1093/infdis/jiro14

PMid:21335562 PMCid:PMC3069728

21. Duong V, Ly S, Lorn Try P, Tuiskunen A, Ong S, Chroeung $\mathrm{N}$, et al. Clinical and virological factors influencing the performance of a NS1 antigen-capture assay and potential use as a marker of dengue disease severity. PLoS Negl Trop Dis. 2011;5(7):e1244.

http://dx.doi.org/10.1371/journal.pntd.0001244

PMid:21811645 PMCid:PMC3139664 